\title{
Science Teaching and Learning in Japan and the Philippines: A Comparative Study
}

\author{
Tupas Fernan Peniero ${ }^{1,2,3, *}$, Matsuura Toshihiko ${ }^{3}$ \\ ${ }^{1}$ Department of Biology, Northern Iloilo Polytechnic State College, Philippines \\ ${ }^{2}$ International Research Fellow, Japan Society for the Promotion of Science, Japan \\ ${ }^{3}$ Laboratory of Biotechnology and Bioengineering, Hokkaido University of Education, Japan
}

Received January 16, 2020; Revised February 28, 2020; Accepted March 12, 2020

Copyright $\mathrm{O} 2020$ by authors, all rights reserved. Authors agree that this article remains permanently open access under the terms of the Creative Commons Attribution License 4.0 International License

\begin{abstract}
This study aims to compare the science curriculum in Japan and the Philippines. Results show that the lesson plan is a requirement in both countries. But Japanese has no fixed standard and in the Philippines, it is found in the Teachers' Guide and ready-made lesson plan. Each science teacher in Japan and the Philippines created instructional materials to make science teaching fun and interesting. The time allotment for both countries is different. In Japan, around 45 to 50 minutes for 2 to 3 days a week in all grade levels. While in the Philippines, 1 to 4 times a week in elementary and junior high school, and 80 minutes for the whole year in senior high school. Also, science classes in Japan have only around 35 students, but more than 40 students in the Philippines. During the experiment, each group in Japan is composed of 4 members, while around 8 to 10 in the Philippines. The scarcity of science facilities and equipment is one common perennial problem in the Philippines. But in Japan, state-of-the-art materials are used during laboratory activities and many Japanese science teachers are still creating innovations. Japan has no specific guidelines for the grading system. But Filipino students are graded base on the standard. All science teachers in Japan and the Philippines take licensure examination before allowing them to teach at any grade level. Both countries have positive and negative points in the implementation of the science pedagogy. Learning from each other's best practices will help the science curriculum.
\end{abstract}

Keywords Teaching Materials, Classroom Setting, Grading System, Science Teachers, Professional Development

\section{Introduction}

Education always helps members of society by providing essential understanding and expertise to become functional individuals. Education is an investment for every person (Abulencia, 2015). Article in Word Bank, education is a tool to reduce poverty to improve the well-being of the people but the proper investment is required (Oteyza, 2012). Thus, Japan and the Philippines are two countries that value education a lot. They were always upgrading quality education through various innovations but differ in various aspects. Ministry of Education Culture Sports Science and Technology (MEXT) is one of the ministries of the Japanese government that regulates almost all aspects of the education system and process in Japan (McMurray, 2018). In the Philippines, the basic education system is managed by the Department of Education (DepEd), and the tertiary education by the Commission on Higher Education (CHED).

The Course of study is linked to active learning that starts in 1999, and is planed to create an active learning program in 2022 as well as active learning methodology in Science. This is to develop social skills and global awareness. Also, the ministry focus on developing autonomous learning and critical thinking skills; thus, each municipality can adopt certain best practices. And, it is also to support education based on the needs of the Japanese within each locality (McMurray, 2018). In 2020, English would become an official subject in Grade Five and Grade Six, and high school students would get new classes in geography, Japanese and modern history (Ellis, 2004, cited in McMurray, 2018; MccRostie, 2017). MEXT in 2000 has engaged robust importance in the effect of globalization; thus, many changes take place in the revision of the new Course of Study (Tahira, 2012).

The Philippine curriculum was patterned from Spaniard as well as the US curriculum. For example, science in the previous curriculum was called Science and technology after the US learned that the Russian launched the Sputnik 
in 1958 (A Maven Channel, 2019). But with rapid development and global competition, K12 through various stakeholders' deliberation, and a flagship education program of the Aquino Administration was implemented in 2012 (Oyteza, 2012). The unique features are the establishment of early childhood education, the curriculum is appropriate for Filipino learners, using a progression approach as well as the utilization of the local dialects, and also the implementation of Senior High School (SHS) tracks (Gatdula and Gayeta, 2019).

Basic education in Japan has composed kindergarten, 6 years in elementary, 3 years in junior high school, and 3 years in senior high school. The Philippines under the new curriculum by the virtue of Republic Act 10157 is also known as $\mathrm{K} 12$ Basic Education Program in the school year 2011-2012 (Cabansag, 2014) made of kindergarten, 6 years in elementary, 4 years in junior high school, and 2 years in senior high school. This was based on various studies as well as a proposal to enhance the Philippine basic education (Oteyza, 2012). Japan start School Year (SY) on April 1 and the first Monday of June in the Philippines. The Japanese education system has almost 243 days and was regarded as the longest in the world. The Philippines has around 200 days. Inside a Japanese classroom, there are only 35 or a maximum of 40 students. But in the Philippines, a classroom fit for 45 persons squeezed to house 78 students (Alcober, 2014). Japan has 9 years in compulsory education while the Philippines is ten years.

The science subject starts in grade 3 in both countries. However, science concepts and ideas are already incorporated in other subjects in Kindergarten to grade 2. In Japan, topics like physical and mental health and relationship to the environment are already incorporated. While in first and second-grade science is connected to social studies called Life Environment studies. This subject is focused on animals, plants, and preserving the environment. In the Philippines, science starts in grade 1 in Health and discusses nutrition and personal health, and social studies about the physical environment. "Life environmental studies were created in 1992 for first and second grades. The Japanese government abolished science and social studies. Japanese elementary students study social studies in an integrated science/social studies course. In elementary, both countries handle all major subjects such as Earth Science, Biology, Chemistry and Physics.

This study is anchored on the science curriculum specifically on materials used science pedagogy, classroom settings, and science teachers in the basic education program. To produce educated and concerned citizens, scientific literacy is a critical component. Scientific literacy is the ability to apply scientific knowledge to everyday problem-solving situations. Thus, the science curriculum must be given emphases in today's education system. Science must be a frame in the context that gives meaning to different types of learners. here were studies engaged in comparing Japan and the Philippines Science Education Curriculum. However, the studies conducted about the science curriculum in Japan and the Philippines were during the old curriculum in both countries. Thus this study was formulated.

This study is mainly concerned with teachers' and students' relationships in the science curriculum in Japan and the Philippines. Thus, Paulo Freire Pedagogy of the Oppressed was utilized as a theory. Paulo Freier Pedagogy of the oppressed is about the critical theory of society that has as its object human beings as producers of their historical form of life" (Horkheimer 1993, 21; cited in The Educationist, 2019). Furthermore, he added, "critical" theory differed from 'traditional' theory in its focus "to liberate human beings from the circumstances that enslave them" (Horkheimer 1982, 244; cited in the Educationist, 2019). And this central concern for human liberation led the critical theorists to reject the separation of philosophy (dealing with normative claims of justice, morality, etc.) and (empirical and interpretative) social science and to claim that a critical theory should attempt, at the same time, to be critical (what is wrong with the prevalent social conditions), be normative (establish viable goals as well as norms for criticism) and practical (identify agents to bring about the change and answer how best it can be brought about). This study tends to improve the science curriculum in Japan and the Philippines.

An effective teacher possesses a positive outlook toward students' development by designing systematic active learning (Wong, 2009; cited by Cicek and Tok, 2014). This can be a showcase and reflected in the lesson plan. Both instruction and classroom management are the benefits of the operative Lesson plan. This can help teachers for a time allotment, in-depth of instruction but above all how teachers will represent the lessons to the learners (Borch, 2007; cited by Cicek and Tok, 2014). Cicek and Tok (2014) suggested that the lesson plan must be ready before the classes start to see the necessary arrangement if needed. Also, they added that in doing lesson plan teachers must priority its practicability as well as be usable in all aspects of teaching and learning. In the Philippines, lesson planning has been isolated work as an individual task by Filipino teachers. They can decide how the lesson will be delivered as well as materials to be used and the assessment of learners. The study of Chetty et al. (2014), revealed teachers played an important role in students' academic and life-long success. Also, Clements et al. (2013) agreed that in students' achievement in mathematics teachers have big roles to play. The quality of professional enhancement can improved classroom practices and resulted in a significant effect on students' performance (Wenglinsky; 2001; cited in Lomibao, 2016).

Moreover, other devices and tools that support teaching and learning is the instructional material (IM). IM is always in the form of various visual aids that help all 
subject areas. Ogaga et al. (2016) revealed a significant relationship between the performance of students in social studies suing IM. IM increases the retention rate of learners but the selection of appropriate visual aids is very important as well as its availability and uniqueness of the materials. Similar to Social Studies, Science also requires IM to study the subject matter. Many students were complaining about the difficulty of the subject; thus, teachers must be innovative and creative to increase interest among students in Science. But Tominez et al (2013) stated that using IM in instruction teachers must consider different factors such as characteristics of IM, age, and level of students as well as attendance to training and seminars by teachers.

Also, time allocation and classroom settings are important in both countries. The amount of time devoted to the education of children is a central resource in the educational process. In Japan, class hours increased from 105 to 140 in the new Course of Study in Junior High School (JHS) (Tahira, 2012). But in the Philippines, DepEd states that a total of 310 min or 5 hours and 10min per day is allocated for grade 2 for the entire academic year (DepEd Order No. 31, s. 2012). The class also matters in learning. Japan has an average of 35 students per class, and 40 plus in the Philippines. Henceforth, Abulencia (2015) revealed that several classrooms, buildings, chairs, restrooms, LCD, computers, internet connections, and others were one of the limitations in the Philippine education system.

Effective science teachers have a large array of instructional strategies and methods to produce successful learners. Also, operative science teachers always consider learning environments and materials for students to learn effectively. Education is constantly changing; thus, professional growth is one way to stay on current knowledge and practices. Professional development of teachers is required to bring a strong information base in science and enables them to acquire new knowledge (Gatdula and Gayeta, 2019). One common problem in the Philippines is allowing teachers to teach not their field of specialization (Alonsabe, 2011). One of the key issues in the modification of the new Japanese Course of Study is the support for teachers. Researchers have found out that even MEXT backing for teachers' development more training programs are needed. The lack of confidence among teachers is additional disputes (Tahira, 2012). Lansangan et al. (2015) showing that teachers are aware of the meaning of quality education. And one common problem in the Philippines is allowing teachers to teach not their field of specialization. Also, the availability of teachers in schools has enhanced as a result of recent teacher hiring efforts. However, there are signs of growing inadequacy in teacher distribution because of weaknesses in teacher apportionment systems. Teacher truancy rates in elementary and high schools are generally low compared to other countries. However, they tend to be high in highly urbanized cities. There have been big improvements in the hiring process but significant delays still exist. Teacher performance on content knowledge assessments is poor and professional development systems are inadequate (The World Bank, 2019).

Even though Japan has excellent reputations in terms of the science curriculum but they are still facing backlash on how they force students to cope with the global trends. For decades, as for similar problems and issues in the science curriculum in the Philippines but the Filipino curriculum, experts are working 24-7 to find solutions in this continuing glitches. Thus, this study was formulated to learn from each other' $s$ best practices.

This study aims to compare science teaching and learning in Japan and the Philippines. Speficillay, it focus on lesson plans, instructional materials, time allotment, classroom setting, grading system, and science teachers.

\section{Methods}

\subsection{Research Design}

This qualitative research use the case study. This research design was utilized to intensively analyze the implementation of the science curriculum in the basic education program in Hakodate, Hokkaido, Japan and Estancia, Iloilo, Philippines during School Year (SY) 019-2020.

\subsection{Methods of Research}

This study employed methods such as ethnographic research, automated micro-targeting, interviews, and document analysis. In Japan, ethnographic research was used by visiting and observing science classrooms in elementary, junior high school and senior high school. But in the Philippines, automated micro-targeting was selected because social media like Facebook was the main tool during the interview. Then, one on one interview was organized in some selected science teachers in both countries. All the documents related to science teaching were collected.

\subsection{Informants.}

The informants in this study were science teachers from Japan and the Philippines. Very few students were selected and observed during the science lesson.

\subsection{Instruments.}

The instrument utilized in this study was ready-made-questionnaire act as a guide during the interview. These 5 open-ended questions allow the informants to respond independently. A tape recorder was 
used in the interview to capture all the details of the responses of the informants. Furthermore, materials like the course of study, curriculum guide, science teaching materials taken from the websites were also used.

\subsection{Analysis.}

The replies from the interviews were transcribed, coded, themed and triangulated. The observations and documents were also analyzed.

\subsection{Ethical Consideration}

All the informants were given a codename. All the data collected were destroyed after the completion of the study. But prior to the engagement of the study permit were distributed for the approval of the school heads.

\section{Results and Discussions}

\subsection{Lesson Plan in Science Class}

Both Japan and the Philippines have a standard lesson plan for science. This was regulated by MEXT in Japan, and DepEd in the Philippines. The Japanese lesson plan is not fixed, but the Filipino teacher has a ready-made lesson plan called Teacher's guide provided by the national government. Every lesson, Japanese science teachers create their lesson plan using localization and contextualization. They also plan materials even they have state-of-art facilities. Some schools, a group of teachers work together to an organized lesson plan. With the help of the Teacher's Guide, Filipino science teachers work independently. One unique feature of the Philippine Science Lesson is about using localization and contextualization. But both countries are utilizing these concepts.

In Japan, there are several cases of how the lesson plan is check. Being a licensed teacher, and trained in college as well as in various seminars about lesson planning, nobody checks lesson plan daily. But in a special event, a committee is organized to assess the lesson plan. Also, the principal or headteacher is tasked to evaluate the lesson plan. Principals organize meetings during which teachers with varying levels of experience identify an area of need in the classroom, research intervention options and create a lesson plan. One teacher then uses this sample lesson in the classroom, with the other teachers observing (Center on International Education Benchmarking, 2019).
While in the Philippines, only the principal and headteacher check the teacher's lesson plan every day. The ready-made lesson plan is provided by the government; teachers are required to $\log$ in identifying the lesson for the day. The lesson plan helps both science teachers in Japan and the Philippines to manage the time properly.

The two countries have different approaches on how to enhance and implement a lesson plan for effective science performance among learners. Also, allowing other experts to criticize lesson plans is a good strategy in the Japanese science curriculum. Japanese science teachers create lesson plan daily but most of the Filipino counterparts are defended on ready-made provided by the national government.

\subsection{Instructional Materials (IM) in Science Class}

There are many types of instructional materials used in science teaching in Japan and the Philippines such as science textbooks, science or laboratory activity, activity sheets, and visual aids. Science textbooks as references are the most common. But in Japan, teachers create science activities every day but Filipino are reliant on the teacher's guide provided by the national government. Even with all the facilities available, Japanese science teachers create visual aids generated from cheap and recycled resources but their Filipino counterparts are working hard to provide quality and interesting methods but still hook on traditional approaches due to lack of facilities. This is defined as resources that bring together and support instruction (Janovsky, 2019).

Comparing the two countries about science instructional materials, Japan almost has positive features but in the Philippines negative points are alarming. The best practices of the Japanese science curriculum can help improve Philippine science education.

\subsection{Time Allotment in Science}

Table 1 summarizes the time allotment in science in Japan and the Philippines. The student is given time to do projects, activities in clubs and organizations and also sports and other extra-curricular activities.

Time allotment in Japan is not heavy compared to the Philippines. The Japanese students have time to do other extra co-curricular activities but the Filipino students usually go home after class because they are tired and drained. The school condition also affects the interest of Filipino learners.

Table 1. Time Allotment in Science in K 12 in Japan and the Philippines

\begin{tabular}{|c|c|c|c|c|}
\hline \multirow{2}{*}{ Grade/Year Level } & \multicolumn{2}{|c|}{ Japan } & \multicolumn{2}{|c|}{ Philippines } \\
\cline { 2 - 5 } & Time Allotment & No. of Days per Week & Time Allotment & 1 hrs. \\
\hline Elementary & $45 \mathrm{~min}$. & 3 & $1 \mathrm{hrs}$. & 4 \\
\hline JHS & $50 \mathrm{~min}$. & $2-3$ & $80 \mathrm{hrs} / \mathrm{sem}$ & 4 \\
\hline SHS & $50 \mathrm{~min}$. & $2-3$ & $2-3$ \\
\hline
\end{tabular}




\subsection{Science Class in Japan and the Philippines}

In Japan, there are around 30 students but not more than 40 inside the class. In some places, they still have more than 70. The lack of classrooms is one of the problems causing a large number of students per class in the Philippines. There are only three sections in one school but in the Philippines there is almost an average of around 5 sections in a small school and more 12 in big school. Big cities like Metro Manila, and Cebu have two shifts per day. Shift one starts from 5:30 and ends around noon, and the second shift will be 12:30 to 6:00 PM. During a science experiment in Japan, there are only 4 members in a group. Teachers see to it that all students have science materials. The scarcity of science equipment and facilities in the Philippines results in a large number in one group. Most of the time there are 8 to 10 students per group. Thus, in the lower section seldom learners manipulate science equipment.

DepEd should try to adopt the Japanese system to improve learners' performances.
Figure 1 depicts a science class in elementary, JHS, and SHS in Japan. Inside a science class in Japan regardless of grade level, you can always see active learning. All students are participating in all science activities. They are all joining in the class discussion.

Science lecture is using active learning, this allows learners to discuss lessons independently and dynamically. Regardless of the level of students, all of them are allowed to participate. Lesson study is an effective method used by Japanese teachers for so many years, even other western countries already have adopted this innovation (Lucenario et al. 2016).

Figure 2 showing the actual scenario of science class in K 12 in the Philippines. Traditionally, the same approach is utilized in science class. But in SHS-STEM Track facilities like Led TV, projectors and laptop are used by science teachers.

The teacher-centered approach is still very common. They usually used blackboard and chalk methods. Also, they stated that additional functions hinder them to do innovations in science teaching.
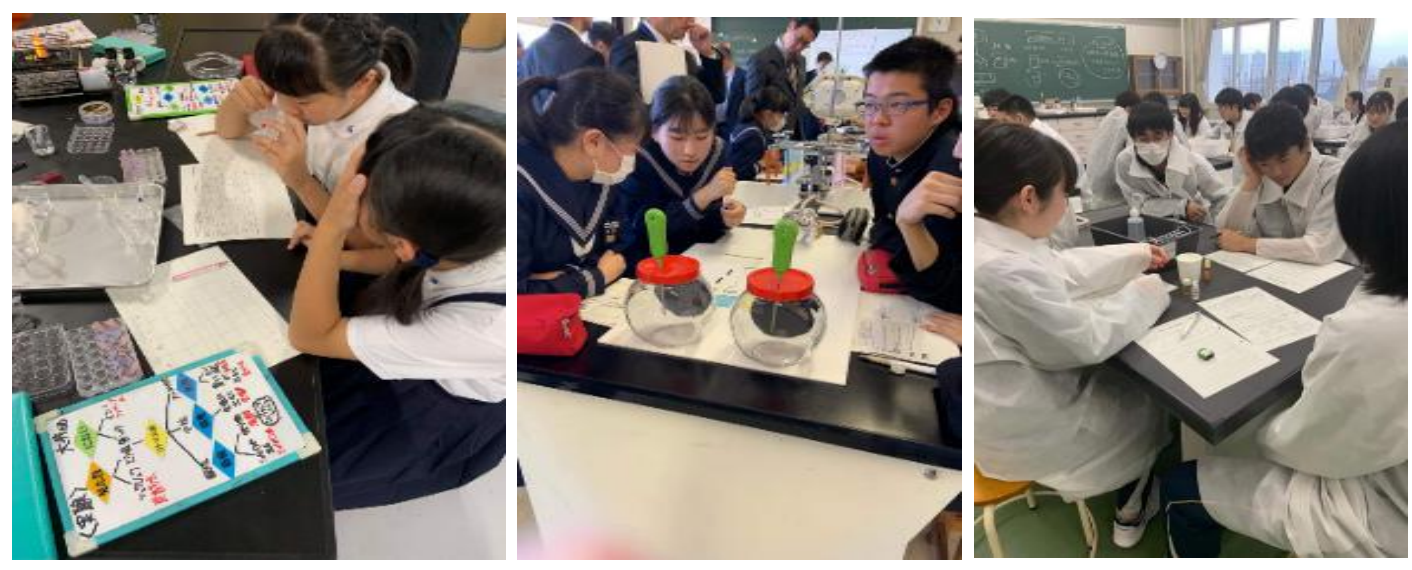

Elementary JHS SHS

Figure 1. Science class in Elementary, JHS, and SHS in Japan
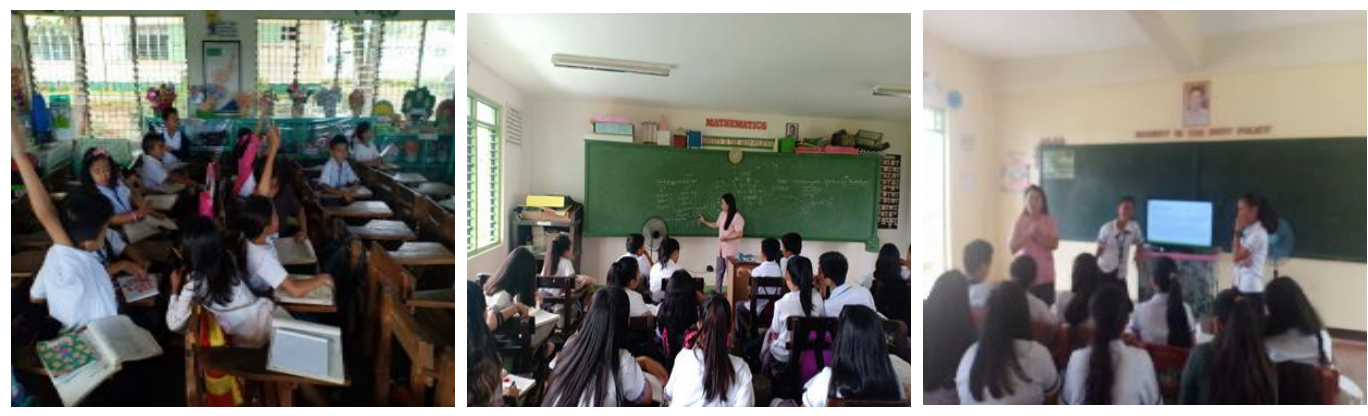

Elementary JHS SHS

Figure 2. Science class in elementary, JHS, and SHS-STEM Track in the Philippines 


\subsection{Grading System in Science Class}

Japan has no specific standard for the grading system. They don't have exams until the fourth grade because a higher emphasis is put on developing responsibility in youth and ensuring children are capable of cleaning, caring, and being polite. This is about building a good manner and develop their character. There is no specific grading system in Japan. They all are set to take seriously a compulsory examination. All students in elementary are promoted to the next grade level even they failed the exam. To be accepted in SHS and accepted in the best school, they have to pass the entrance examination. This is one of the reasons why Japanese students study hard. They value quality education. Parents are more concerned about entering reputable schools; thus, they send their children to the best schools around their areas. The grading system in Japan is to assess poor students as well as bright ones. In most schools, students are graded from 1 to 5 on their report cards at the end of each term. Five (5) is being the highest. Tests and exams are usually scored out of 100 . Right answers are usually marked with a circle and marked cross for the wrong answer. According to Alonsabe (2011), they rest assured that students do not flunk during elementary and junior school.

There is a definite grading system in the Philippines. Filipino students in all grade levels usually take quizzes every day. They also take a summative or monthly examination, as well as periodical or quarterly exams. Effective School Year (SY) 2015 - 2016 the new grading system is composed of summative assessments such as Written Work (40\%), Performance Tasks (40\%), and Quarterly Assessment (20\%) will form the bases for the grade computation. Written Work or WW is to make sure students can express skills and contents in written form. While Performance Task or PT is to let learners show what they know and can do in diverse ways. And Quarterly Assessment or QA is to measure student learning at the end of the quarter. Furthermore, the report card shall show how the students perform based on proficiency levels such as B for Beginning, D for Developing, AP for Approaching Proficiency, $\mathrm{P}$ for Proficient and A for Advanced with Equivalent Numerical Value of $74 \%$ and Below, $75-79 \%, 80-84 \%, 85-89 \%$ and $90 \%$ and Above, respectively. The new Senior High School grading system for core subjects is $25 \%$ for $\mathrm{WW}$, $50 \%$ for PT and $25 \%$ for QA. The new k to 12 grading system has 60 as a minimum grade but will have a converted rating of 75 in the report card. The lowest grade a student can get is rather 60 for the quarterly and final grades. Since the new grading system also use fewer components and launch a new transmutation table, it makes it simpler for teachers to compute the grades $\left(\right.$ DepED, 2015 $\left.{ }^{\mathrm{A}}\right)$. Deped $\left(2015^{\mathrm{B}}\right)$ clarifies that all students with 2 failing grades are still promoted to the next grade levels provided they will be given additional learning opportunities.
At the end of the school year, many teachers indorsed learners for the next grade level even they failed in the class. Conducting remedial classes during summer break is a burden to the teachers.

\subsection{Science Teacher in Basic Education in Japan and the Philippines}

Both Japan and the Philippines required professional license to teach in government-owned institutions. Japanese and Filipino teachers take general license in elementary and specializations in secondary. Both Japanese and Filipino science teachers attend in-service training as professional development to update and upgrade about new trends in education.

Best teachers are placed in a school that they are needed the most in Japan but in the Philippines they are following localization. Also, new Japanese teachers worked with experienced teachers to enhance the stronger relationship with peers but seldom you can see in the Philippines.

Most of the Japanese science teachers in basic education are graduates of the national university in education and major in science-related courses. But the Filipino science teachers finishing Bachelor of Elementary Education (BEED) teach all subject areas. However, some science teachers finishing Bachelor of Science in Industrial Education and Practical Arts, and BEED major in Reading. In JHS, most of the teachers are Bachelor of Secondary Education majoring in Science, Bachelor of Science in Biology, and the others are majors in English. But in SHS, all the teachers major in science. The lack of teachers in previous years resulted in hiring teachers not majoring in science. Yet, in the graduate program, most of them take Masters of Arts in Education major in Management in elementary but in JHS and SHS most of them major in science. Teaching SHS-Science, Technology, Engineering, and Mathematics track teachers are required to take graduate programs related to science. They are allowed at least 6 units. Because of the lack of specialized teachers, DepEd hired teachers without a license. They were given 5 years as probationary. This showed that all Japanese science teachers are equipped compared to Filipino science teachers.

Almost all Japanese science teachers in elementary, JHS, and SHS enrolled in science courses in graduate programs. Many Filipino elementary teachers took the master's program in management to become school heads, while JHS teachers studied general science to become master teachers, and SHS were required to take the vertical course. Hence, the Philippine government should allocate a bigger budget for In-Service Training for Teachers, as well as professional growth (Abulencia, 2015).

Both Japan and the Philippines science teachers are engaged in active learning. However, it is very prominent in the Japanese education system. The Philippines adopted 
Lesson Study but could sustain because of so many problems and issues encountered by the teachers. Lansangan et al. (2015) exposed that teacher-respondents have created various strategies and methods in facilitating learning. These innovations had led to good performances of the students.

In Japan, teaching is a respected profession, and teachers have traditionally been paid around US\$63,215 per year better than in the Philippines that Teachers I only received \$7,200 per annum (Center on International Education Benchmarking, 2019). This is a big difference

Table 2 summarizes the training attended by a Japanese Science teacher. The new trend in Japan is Society 5.0.
Also, teachers are still suing active learning in instruction. The training in every grade level is focused on and showcasing on Best Practices in the science curriculum.

After the presentation, discussion opportunities were organized. All science teachers, enthusiasts, and experts were given time to share opinions, comments, and suggestions of the demonstration teaching.

Table 3 presents the training attended by science teachers in the Philippines. In-Service Training for Teachers or INSET is the most common activity joined by all educators. The contents of the training are mostly teachers' activities. They were topics also about enhancement science pedagogy.

Table 2. Pieces of training Attended by K12 Science Teachers in Japan

\begin{tabular}{|l|l|l|}
\hline Elementary & Junior High School & Senior High School \\
\hline Workshop for in-service teachers & $58^{\text {th }}$ Hokkaido JHS conference on science education & In-school training \\
\hline Research Conference on Advance Education & Research Conference on Advance Education & \\
\hline Workshop for Science Teachers & Workshop for Science Teachers & \\
\hline $60^{\text {th }}$ Hokkaido ES Conference on Science education & In-school training & \\
\hline In-school training & & \\
\hline
\end{tabular}

Table 3. Pieces of training Attended by K12 Science Teachers in the Philippines

\begin{tabular}{|l|l|l|}
\hline Elementary & Junior High School & Senior High School \\
\hline $\begin{array}{l}\text { In-Service Training for Teachers } \\
\text { (May and October every year) }\end{array}$ & $\begin{array}{l}\text { In-Service Training for } \\
\text { Teachers } \\
\text { (May and October every year) }\end{array}$ & $\begin{array}{l}\text { In-Service Training for Teachers } \\
\text { (May and October every year) }\end{array}$ \\
\hline Safety in Science & Critical Thinking & Localization and Contextualization of Instructional Materials \\
\hline Lesson Plan Exemplar & Mass Training for K 12 & Common Topics in K12 Teaching \\
\hline $\begin{array}{l}\text { Mass Training for K 12 Basic } \\
\text { Education Program }\end{array}$ & Capability Building for K 12 & Capability Building on Outcome Base Learning \\
\hline Critical Content for Science & & Science Curriculum, Teaching Episodes and Assessment \\
\hline $\begin{array}{l}\text { Rural Initiative } \\
\text { Education Program }\end{array}$ & Contextualization \\
\hline \multicolumn{1}{|c|}{ Science } \\
\hline & SHS Biology II Instructional Materials \\
\hline
\end{tabular}


Continuing professional development is required in the teaching profession. The in-service training for teachers is focused on subject areas compared to the Philippines using the general approach. All training attended by Filipino science must be evaluated and assessed properly.

\section{Conclusions}

Results showed that the lesson plan is a requirement in Both countries. But Japanese has no fixed standard for the lesson plan, and in the Philippines, it is found in the Teacher's Guide. But Japanese are working daily to create a unique and effective lesson based on the needs of the learners. Many Filipino science teachers are relying on the ready-made lesson plans provided by DepEd. This allows teachers not to create a lesson plan centered on the needs of the learners and use local resources. Each science teachers in Japan and the Philippines created instructional materials to make science teaching fun and interesting. But because Filipino has no time due to other designations, traditional approaches are employed. The time allotment for both countries is different. In Japan, around 45 to 50 minutes for 2 to 3 days a week in all grade levels. While in the Philippines, 1 to 4 times a week in elementary and junior high school, and 80 minutes for the whole year in senior high school. Also, science classes in Japan have only around 35 students but more than 40 students in the Philippines. These permit Japanese students to do other activities but the Filipino counterparts are drained and tired. During the experiment, each group in Japan is composed of 4 members, while around 8 to 10 in the Philippines. The scarcity of science facilities and equipment is one common perennial problems in the Philippines. But in Japan, state-of-the-art materials are used during laboratory activities but many Japanese science teachers are still creating innovations. Japan has no specific guidelines for the grading system. But Filipino students are graded base on the standard. All science teachers in Japan and the Philippines take licensure examination before allowing them to teach at any grade level. The lack of qualified science teachers in the Philippines is always a perennial problem. The training in Japan is about Society 5.0 focusing on active learning. In the Philippines, they have In-Service Training for Teachers or INSET every May and October every year but not focus on current trends like Education 4.0 because of the newly implement K12 Basi Education Program. Salary is one big factor that affects quality education in both countries.

\section{Acknowledgments}

This work was supported in part by JSPS KAKENHI Grant Number 19F19014. We like to extend our heartfelt gratitude to the principal and teachers from public schools in Hakodate, Hokkaido, Japan, and Estancia, Iloilo, the Philippines for allowing us to visit and observe their schools.

\section{REFERENCES}

[1] A Maven Channel. (2019). Sputnik Launched. Retrieved from https://www.history.com/this-day-in-history/sputnik-launc hed

[2] Abulencia, A.S. (2015). The Unraveling of K-12 Program as an Education Reform in the Philippines. South-East Asian Journal for Youth, Sports and Health Education, 1 (2), 229-238.

[3] Alcober, N. (2014). Too many students, too few classrooms. Retrieved

from https://www.manilatimes.net/2014/06/02/n ews/top-stories/too-many-students-too-few-classrooms/10 1219/101219/.

[4] Alonsabe, O. C. (2011). Comparative Studies of Education System. Retrieved from https://olga-compedsys.blogspot.com/2011/03/japan-educa tion-system.html.

[5] Cabansag, M. G. S. (2014). Impact Statements on the K-12 Science Program in the Enhanced Basic Education Curriculum in Provincial Schools. Retrieved from https://www.questia.com/library/journal/1P3-3296082771/ impact-statements-on-the-k-12-science-program-in-the.

[6] Center on International Education Benchmarking. (2019). Japan: Teacher and Principal Quality. Retrieved from http://ncee.org/what-we-do/center-on-international-educati on-benchmarking/top-performing-countries/japan-overvie w/japan-teacher-and-principal-quality/.

[7] Chetty R., Friedman, J. N., and Rockoff J. E. (2014). Measuring the impacts of teachers II: teacher value-added and student outcomes in adulthood. Am Econ Rev 104(9):2633-2679. In: Blazar D (2015) Effective teaching in elementary mathematics: Identifying classroom practices that support student achievement. Econ Educ Rev $48,16-29$.

[8] Cicek, V., and Tok, H. (2014). Effective Use of Lesson Plan to Enhance Education in US and Turkish Kindergarten Thru 12th Grade Public School System: A Comparative Study. International Journal of Teaching and Education, II (2), 10-21.

[9] Clements, D., Agodini, R., and Harris, B. (2013) Instructional practices and student math achievement: correlations from a study of math curricula. National Center for Educational Evaluation and Regional Assistance. Institute of Education Sciences. Retrieved from http://ies.ed.gov/ncee/pubs/20134020/pdf/20134020.pdf.

[10] DepED Order No. 31 s. 2012. Policy Guidelines on the Implementation of Grades 1 to 10 of the K12 Basic Education Curriculum effective school year 2012 - 2013. Pasig City, Philippines: DepEd.

[11] DepEd. (2015A). Order No. 8, s. 2015 Policy Guidelines on 
Classroom Assessment for the $\mathrm{K}$ to 12 Basic Education Program. Pasig City, Philippines: DepEd.

[12] DepEd. (2015B). Order No. 29 s 2015. Clarifications to DepEd Order No. 8, S. 2015 (Policy Guidelines on Classroom Assessment for the $\mathrm{K}$ to 12 Basic Education Program. Pasig City, Philippines: DepEd.

[13] Gatdula, S. L., and Gayeta, N. E. (2019). Grade-Based Strategy in Teaching Senior High School Life Science. Asia Pacific Journal of Multidisciplinary Research, 7 (3). 6-14

[14] Janosky, A. (2019). Instructional Materials; Definition, Example, and Evaluation. Retrieved from https://study.com/academy/lesson/instructional-materials-d efinition-examples-evaluation.html.

[15] Lansangan, M. L. G., Quiambao, D. T., Baking, E. G., Nicdao, R. C., Nuqui, A. V., and Cruz, R. C. (2015). Correlates of Students' Academic Performance in Intermediate. Journal of Business and Management Studies, 1 (2), 1-7.

[16] Lomibao, L. S. (2016). Enhancing Mathematics Teachers' Quality through Lesson Study. Springerplus, 5 (1), 1590. DOI:1186/s40064-016-3215-0.

[17] Lucenario, J. L. S., Yangco, R. T., Punzalan, A. E., and Espinosa, A. A. (2016). Pedagogical Content Knowledge-Guide Lesson Study: Effects on Teacher Competence and Students' Achievement in Chemistry. Educational Research International, (2016).http://dx.doi.org/10.1155/2016/6068930.

[18] McMurray, D. (2018). MEXT's new Course of Study guidelines to rely on active learning. The Language Teacher, 42 (3). Tokyo, Japan: The Japanese Association for Language Teaching Publication.

[19] McRostie J. (2017). Education in Japan in 2016: New Solutions and Age-old Problems, from teaching English to bullying. Retrieved fromhttps://www.japantimes.co.jp/community/2017/01/25/ issues/education-japan-2016-new-solutions-age-old-proble ms-teaching-english-bullying/\#.XKbI3kxuLIU

[20] Ogaga, G.A., Wallace, I., and Egbodo Benson, A. (2016). Effects of Instructional Materials on the Teaching and Learning of Social Studies in Secondary Schools in Oju Local Government Area of Benue State. International Journal of Current Research, 8 (7), 33859-33863.

[21] Oteyza, K. C. O. (2012). Enhanced K to 12 Basic Education Program: opportunities and challenges. Economic Issue of the Day. Makati City, Philippines: Philippines Institute for Development Studies.

[22] Tahira, m. (2012). Behind MEXT's new Course of Study Guidelines. The Language Teacher (Feature Article), 36 (3), 3-8.

[23] The Educationist. (2019). Paulo Friere's Pedagogy of the Oppressed. Book Summary. News and Views on Education from Around the Globe. Retrieved fromwww.theeducationist.info/paulo-freires-pedagogy-opp ressed-book-summary/.

[24] The World Bank. (2019). Assessing Basic Education Service Delivery in the Philippines: Public Education
Expenditure Tracking and Quantitative Service Delivery Study. Retrieved from https://www.worldbank.org/en/country/philippines/publica tion/assessing-basic-education-service-delivery-in-the-phili ppines-public-education-expenditure-tracking-and-quantita tive-service-delivery-study.

[25] Tominez, B. A., de la Cruz, L. M., and Gabatino, B. B. (2013). Usage of Instructional Materials among Teacher Education Faculty in Nueva Vizcaya, Philippines. IAMURE International Journal of Education, 6 (1).

[26] Wieczorek, C. C. (2008). Comparative Analysis of Educational System of American and Japanese Schools: Views and Vision. Educational HORIZON (Winter), 99-112. 